\title{
MORPHOLOGICAL AND MOLECULAR DIFFERENTIATION OF THE CROATIAN POPULATIONS OF QUERCUS PUBESCENS WILLD. (FAGACEAE)
}

\author{
JOSIP FRANJIĆ ${ }^{1}$, ZLATKO LIBER ${ }^{2}, \check{Z ̌ E L J K O ~ S ̌ K V O R C ~}^{1}$, \\ MARILENA IDŽOJTIĆ ${ }^{1}$, RENATA ŠOŠTARIĆ ${ }^{2}$, ZvJEZDANA STANČIĆ ${ }^{3}$ \\ ${ }^{1}$ Department of Forest Genetics, Dendrology and Botany \\ Faculty of Forestry, University of Zagreb \\ Svetošimunska 25, HR-10000 Zagreb, Croatia \\ e-mail: jozo.franjic@zg.t-com.hr \\ ${ }^{2}$ Department of Botany, Faculty of Science \\ University of Zagreb \\ Marulićev trg 20/2, HR-10000 Zagreb, Croatia \\ ${ }^{3}$ Stjepana Radića 28, HR-49221 Bedekovčina, Croatia \\ (Received: June 7, 2005. Accepted: March 17, 2006)
}

\begin{abstract}
Taxonomy of the genus Quercus L. is very complicated and often controversial because of its great variability and intense gene flow among the related species. The purpose of this research was to determine morphological and molecular variation, relationships and taxonomic status of the Croatian populations of Quercus pubescens Willd. using morphological analysis of the leaves and RAPD-PCR technique. The results of the morphological and molecular analyses were very similar, both showing differentiation of the southern (Mediterranean) from the northern (Continental) pubescent oak populations. These two groups were clearly separated and the estimated gene flow among the populations that belong to different groups $(\mathrm{Nm}=1.38)$ is significantly less than among the populations that belong to the same group $(\mathrm{Nm}=3.70)$. The obtained results were compared to the available studies. This study confirms a high variability of the $Q$. pubescens populations, but differences were not so big to confirm the opinion of existence of several species in this area. The conclusion is that the southern Croatian populations could be pure $Q$. pubescens populations, while the peculiarities of the northern Croatian populations originate probably from the $Q$. petraea introgression.
\end{abstract}

KEY WORDS: Quercus pubescens, population differentiation, morphology, RAPD, introgression, Croatia.

\section{INTRODUCTION}

Genus Quercus L. is characterized by high polymorphism, and complex patterns of variation (Burger 1975; Manos et al. 1999). Hybridization and introgression are often present, even between morphologically and/or ecologically clearly differentiated species. This makes the taxonomy of the genus very complex and often controversial (Burger 1975; Rushton 1993; Franjić 1996).

The results of the morphological, cytological and molecular researches of the European oaks of the section Quercus point to close relation and intense gene flow among different species (Dupouey and Badeau 1993; Samuel et al. 1995; Bussoti and Grossoni 1997; Aas 1998; Bruschi et al. 2000). One of the best examples of such situation is the Quercus pubescens Willd. Some taxonomists suppose that the Quercus pubescens Willd. is divided into several spe- cies $-Q$. pubescens sensu stricto, $Q$. brachyphylla Kotschy, $Q$. congesta $\mathrm{C}$. Presl, $Q$. infectoria Olivier, $Q$. sicula Borzi and Q. virgiliana /Ten./ Ten. (Schwarz 1964; Trinajstić 1974; Pignatti 1997), whereas the others think the differences are not big enough to be recognized as different species (Uzunova et al. 1996; Bussoti and Grossoni 1997; Bruschi et al. 2000).

In fact, like many other oaks, Quercus pubescens hybridizes with related species $(Q$. petraea /Matt./ Liebl., $Q$. robur L.) and therefore, in areas with suitable (intermediary) ecological conditions, hybrids are frequent (Dupouey and Badeau 1993; Aas 1998; Müller 1999; Bruschi et al. 2000).

Pubescent oak is a widespread species of great ecological and silvicultural importance in South and Central Europe. Its great variability allows it to live in different climatic and edaphic environments and to adapt to extreme ecological conditions. Croatian populations of $Q$. pubescens can 
be found in the central part of the distribution range, at the borderline of two different climate areas - Mediterranean and Central Europe - and their study is essential to understand the evolutionary history of this species. In Croatian literature there is a prevailing opinion that in the Mediterranean area, as well as in dry and warm expositions in the continental part of the country, grow two closely related species of pubescent oaks - Q. pubescens Willd. and $Q$. virgiliana (Ten.) Ten. (Trinajstić 1986). Exactly, pure stands of the $Q$. virgiliana are considered to be spread in the outermost southern part, pure stands of the $Q$. pubescens in the northern coastal area, whereas mixed populations grow between these two areas. In addition to that, $Q$. brachyphylla and $Q$. dalmatica, in the outermost southern part of the country, were described as closely related species (Bačić 1996).

The taxonomy of genus Quercus is based on morphological traits and these traits are still crucial to differentiating species within the genus Quercus L. (Dupouey and Badeau 1993; Bruschi et al. 2000). However, in the past fifteen years numerous molecular techniques which enabled systematic researches have been applied (Hillis et al. 1996; Soltis et al. 1998), especially after the polymerase chain reaction (PCR) was developed (Mullis and Falcona 1987; Wolfe and Liston 1998). Many of these techniques have been applied to various taxa of genus Quercus (Moreau et al. 1994; Dumolin et al. 1995; Bacilieri et al. 1996; Howard et al. 1997; Bruschi et al. 2000, 2003a; Muir et al. 2000; Petit et al. 2002), but none for the taxonomy of Quercus pubescens.

Since analysis of the amount and distribution of morphological and genetic variations among and within popula- tions of some species can increase our understanding about its evolutionary history and taxonomy, the purpose of this study was to determine morphological and molecular differentiation of Croatian pubescent oak populations using morphometric analysis of the leaves and RAPD-PCR technique (Welsh and McClelland 1990; Williams et al. 1990). The obtained results could be also important for future breeding and genetic resource conservation programs.

\section{MATERIALS AND METHODS}

\section{Materials}

A total of 100 samples from 10 populations were analyzed (10 trees per population). Distance among trees in population were 50-80 m. They represent the major geographical and ecological characteristics of the natural distribution of this species in Croatia. The populations originated from the next localities: Dilj (45 $\left.17^{\prime} \mathrm{N} ; 18^{\circ} 10^{\prime} \mathrm{E}\right)$, Papuk $\left(45^{\circ} 28^{\prime} \mathrm{N} ; 7^{\circ} 38^{\prime} \mathrm{E}\right)$, Samobor $\left(45^{\circ} 45^{\prime} \mathrm{N} ; 15^{\circ} 39^{\prime} \mathrm{E}\right)$, Grobnik (45 $22^{\prime} \mathrm{N}$; $\left.14^{\circ} 32^{\prime} \mathrm{E}\right)$, Lanišce $\left(45^{\circ} 23^{\prime} \mathrm{N}\right.$; $1^{\circ} 07^{\circ}$ ' E), Pula ( $44^{\circ} 56^{\prime} \mathrm{N}$; $\left.13^{\circ} 51^{\prime} \mathrm{E}\right)$, Jablanac ( $44^{\circ} 42^{\prime} \mathrm{N}$; $14^{\circ} 54^{\prime}$

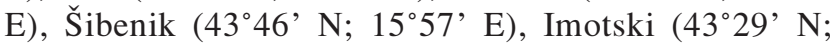
$17^{\circ} 05^{\prime}$ E) and Pelješac (42 $51^{\prime}$ N; $17^{\circ} 32^{\prime}$ E) (Fig. 1).

\section{Morphological analysis}

A very high degree of variation among vegetative characters within individual oak trees is evident in many studies (Blue and Jensen 1988). So, the leaves growing in the light and in the shadow are significantly different (cf. Bru-

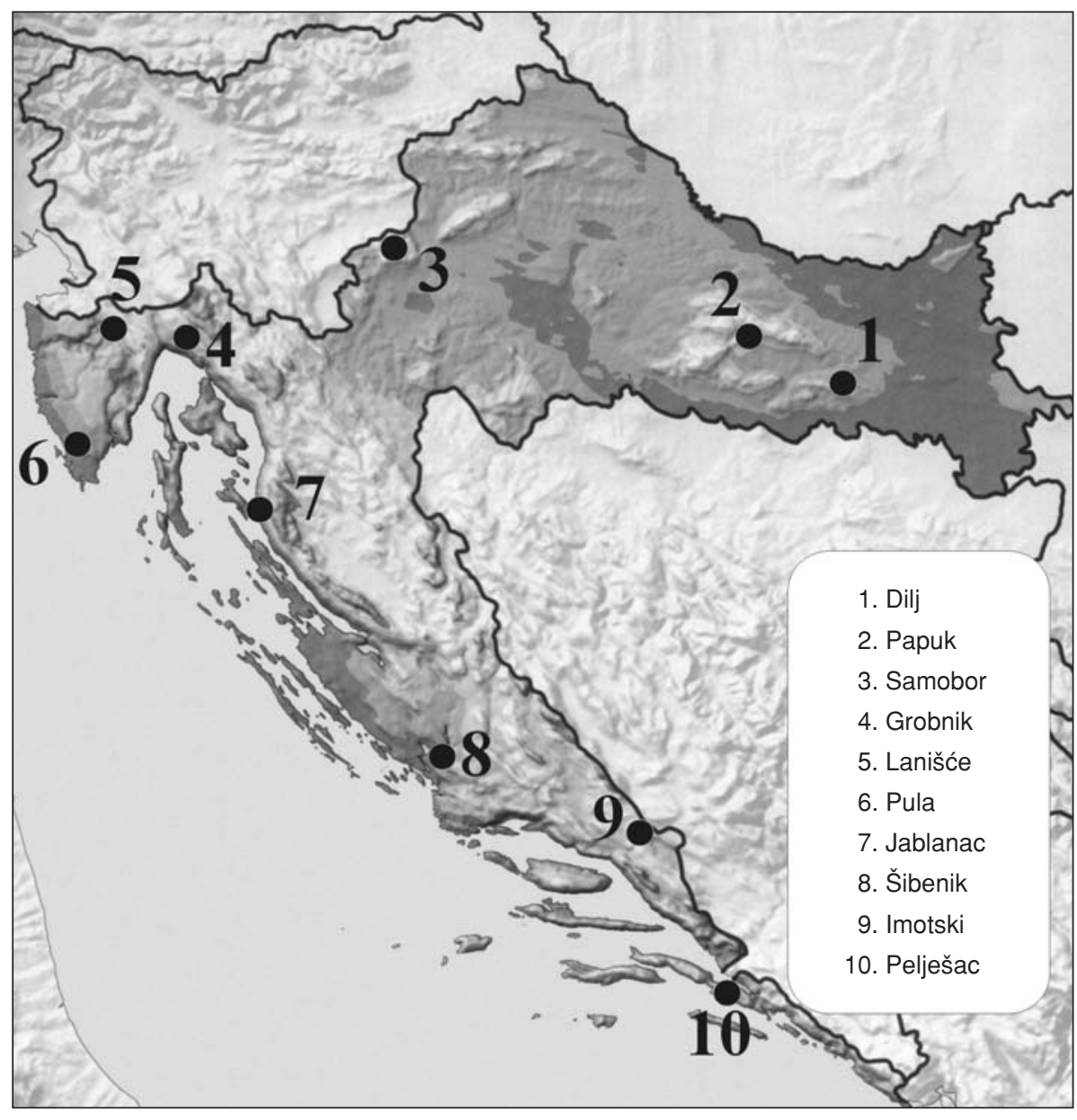

Fig. 1. Geographical position of the analysed pubescent oak populations. 
schi et al. 2003) as are the leaves in various types of shoots (cf. Trinajstić and Franjić 1996). Because of that, only healthy, undamaged and fully developed leaves from the short fertile shoots and from the part of a tree crown exposed to light have been analyzed. Each tree was represented by 50 leaves. For each leaf the following traits have been measured and evaluated - leaf blade length (LL), leaf blade width (LW), distance between the leaf base and the leaf's widest part (WP), petiole length (PL), number of lobes on the left side of the leaf (NLL) and number of lobes on the right side of the leaf (NLR). All parameters have been measured with the accuracy of $0.1 \mathrm{~mm}$. To estimate measurement error, leaves was measured twice using a small subsample of 100 leaves chosen across all samples. The percentage of measurement errors were $0.9-1.6 \%$.

Descriptive statistical methods were used to calculate arithmetic mean values $(\overline{\mathrm{x}})$ and standard deviations (SD) (Sokal and Rohlf 1989). To determine intrapopulational and interpopulational variability of $Q$. pubescens analysis of variance (ANOVA) was used. The analyzed factors were population and tree (tree factor nested inside the population factor). All these statistical data processing methods were done in the program package SAS System for Windows 6.12 (1990). Differentiation of populations was analyzed using cluster UPGMA and the Mahalanobis' distance from the STATISTICA for Windows software (StatSoft, Inc. 2001).

\section{DNA analysis}

DNA isolation: DNAs were extracted from $100 \mathrm{mg}$ of fresh leaf tissue, as described in Dumolin et al. (1995) with some modifications. These modifications included addition of $1 \%$ soluble polyvinylpyrrolidone (PVP-40) and $1 \% 2$ mercaptoethanol in $2 \%(\mathrm{w} / \mathrm{v})$ alkyltrimethylammonium bromide buffer (Sigma M 7635), two extractions with dichloromethane and precipitation of nucleic acids using 2.5 volumes of cold ethanol. The quality and concentration of the DNAs were checked by electrophoresis in $0.8 \%(\mathrm{w} / \mathrm{v})$ agarose and by comparison with $\lambda$ DNA as a standard (Sambrook et al. 1989). Every DNA sample was checked for its clarity and applicability for RAPD (Random Ampli- fied Polymorphic DNA) analysis, so after finishing the DNA isolation, every sample of DNA was diluted to three concentrations $(5,25$ and $50 \mathrm{ng} / 25 \mu \mathrm{l}$ PCR mixture) and preliminary amplified by usage of the same RAPD primer. Only those DNAs which showed constant RAPD banding patterns in these three DNA concentrations were determined as DNAs of adequate purity and quality for the subsequent RAPD analysis (Liber et al. 2002).

DNA amplification and electrophoresis: In total, 27 RAPD primers (Operon Technologies) were used, 20 of which from kit $\mathrm{B}$ and primers OPA-06, -08, -09, -12; OPE$-08,-09$; OPX-04. The total reaction volume was $25 \mu \mathrm{l}$, and it contained $25 \mathrm{ng}$ of genomic DNA, 1x PCR Buffer (Applied Biosystems $\left.{ }^{\circledR}\right), 2.5 \mathrm{mM} \mathrm{MgCl}{ }_{2}, 100 \mu \mathrm{M}$ dATP, dCTP, dGTP and dTTP, $0.36 \mu \mathrm{M}$ 10-base RAPD primer (Operon Technologies Inc.) and 0.75 unit of Taq DNA polymerase (Eppendorf $\left.^{\circledR}\right)$. The amplification profile was 40 cycles of 1 $\min$ at $94^{\circ} \mathrm{C}, 1 \mathrm{~min}$ at $36^{\circ} \mathrm{C}$ and $2 \mathrm{~min}$ at $72^{\circ} \mathrm{C}$. All PCR reactions were done on the GeneAmp PCR System 2700 (Applied Biosystems ${ }^{\circledR}$ ) with a negative control without the DNA. The amplification products were analyzed by electrophoresis in $1.4 \%$ agarose gels, and visualized by ethidium-bromide staining. The molecular weights of the RAPD fragments were determined using 100 bp PCR standard (Bio-Rad).

RAPD data analysis: RAPD bands with the same molecular weight and mobility were treated as identical fragments. In the data matrices, the presence of a band was coded as 1 , whereas the absence of the band was coded as 0 . The analysis of molecular variance (AMOVA; Excoffier et al. 1992) was used to partition the total phenotypic variance within populations and among populations. Additional AMOVA was performed to partition the total variance into: within populations, among populations within regions and between regions. The AMOVA was performed using the GENALEX V5 program (Peakall and Smouse 2001). For each analysis 1000 permutations were performed to obtain significance levels. Nei's pairwise genetic distances among populations were calculated using POPGENE software, version 1.32 (Yeh et al. 1997). Relationships among populations were analyzed using Nei's distances and UPGMA clu-

TABLE 1. Means (x), standard deviations (SD) and ANOVA (F) for measured leaf traits.

\begin{tabular}{|c|c|c|c|c|c|c|c|c|c|c|c|c|c|}
\hline \multirow{2}{*}{$\begin{array}{l}\text { Leaf } \\
\text { variable }\end{array}$} & & \multirow{2}{*}{ Dilj } & \multirow{2}{*}{ Papuk } & \multirow{2}{*}{ Samobor } & \multirow{2}{*}{ Grobnik } & \multirow{2}{*}{ Lanišće } & \multirow{2}{*}{ Pula } & \multirow{2}{*}{ Jablanac } & \multirow{2}{*}{ Šibenik } & \multirow{2}{*}{ Imotski } & \multirow{2}{*}{ Pelješac } & \multicolumn{2}{|c|}{$\mathrm{F}[9,110]$} \\
\hline & & & & & & & & & & & & $A^{*}$ & $\mathrm{~W}^{*}$ \\
\hline \multirow[t]{2}{*}{ LL* } & $\mathrm{x}(\mathrm{mm})$ & 68.8 & 67.8 & 70.5 & 61.7 & 68.3 & 58.1 & 63.5 & 57.1 & 61.6 & 56.8 & 8.46 & 20.17 \\
\hline & $\mathrm{SD}(\mathrm{mm})$ & 11.1 & 12.5 & 12.8 & 12.2 & 9.8 & 10.5 & 11.1 & 9.7 & 10.3 & 11.9 & & \\
\hline \multirow[t]{2}{*}{$\mathrm{LW}^{*}$} & $\mathrm{x}(\mathrm{mm})$ & 46.1 & 46.5 & 46.6 & 41.7 & 47.7 & 41.3 & 44.0 & 40.0 & 42.3 & 43.6 & 3.43 & 17.85 \\
\hline & $\mathrm{SD}(\mathrm{mm})$ & 8.7 & 10.7 & 9.3 & 9.8 & 9.6 & 8.1 & 10.0 & 8.6 & 8.2 & 10.7 & & \\
\hline \multirow[t]{2}{*}{ PL* } & $\mathrm{x}(\mathrm{mm})$ & 11.5 & 14.3 & 11.7 & 9.4 & 12.5 & 8.3 & 12.2 & 10.7 & 10.8 & 9.5 & 9.52 & 32.78 \\
\hline & $\mathrm{SD}(\mathrm{mm})$ & 2.8 & 3.8 & 3.1 & 2.7 & 3.4 & 2.6 & 3.0 & 3.0 & 2.9 & 2.7 & & \\
\hline \multirow[t]{2}{*}{ WP* } & $\mathrm{x}(\mathrm{mm})$ & 40.1 & 38.8 & 37.5 & 33.1 & 39.9 & 31.8 & 34.6 & 31.1 & 33.5 & 31.8 & 7.73 & 16.51 \\
\hline & $\mathrm{SD}(\mathrm{mm})$ & 8.8 & 8.0 & 10.5 & 9.2 & 8.3 & 8.0 & 8.4 & 7.8 & 7.9 & 9.2 & & \\
\hline \multirow[t]{2}{*}{ NLL* } & $\mathrm{x}$ & 5.7 & 5.1 & 5.1 & 5.2 & 4.8 & 5.0 & 5.1 & 4.1 & 5.0 & 4.8 & 5.87 & 32.55 \\
\hline & SD & 1.0 & 1.0 & 0.9 & 1.0 & 0.8 & 0.9 & 0.9 & 0.8 & 1.1 & 0.9 & & \\
\hline \multirow[t]{2}{*}{ NLR* } & $\mathrm{x}$ & 5.8 & 5.1 & 5.1 & 5.3 & 4.7 & 4.9 & 5.1 & 4.0 & 5.0 & 4.8 & 6.87 & 33.17 \\
\hline & SD & 1.0 & 1.0 & 0.9 & 1.0 & 0.8 & 1.0 & 1.0 & 0.8 & 1.1 & 0.9 & & \\
\hline
\end{tabular}

* LL - leaf blade length; LW - leaf blade width; WP - distance between the leaf base and the leaf's widest part; PL - petiole length; NLL - number of lobes on the left side of the leaf and NLR - number of lobes on the right side of the leaf; A - among populations; W - within populations 
ster analyses from the STATISTICA for Windows software (StatSoft, Inc. 2001). From the Nei's pairwise genetic distances (Gst) gene flow between populations was calculated using the equation $\mathrm{Nm}=1 / 4(1 / \mathrm{Gst}-1)$ (Wright 1951).

\section{RESULTS}

\section{Morphological data}

The measured leaf characters were highly variable. There were significant differences among populations and among trees inside populations (ANOVA, $\mathrm{p}<0.001$ ) for all measured leaf traits. The morphological leaf variation was higher within than among populations (Table 1). It could be seen that the continental populations (Dilj, Samobor, Papuk and Lanišce) had higher values of the variables determining the leaf size (LL, LW, PL, WP) than other populations. With respect to the number of lobes (NLL, NLR), the population Dilj was distinguished with its maximum values and the population Šibenik with its minimum ones (Table 1).

UPGMA method showed similar results as descriptive analysis - a clear differentiation of Continental (Dilj, Papuk, Samobor, Lanišće) and Mediterranean populations (Grobnik, Pula, Jablanac, Imotski, Pelješac) (Fig. 2).

\section{Molecular data}

From total of 27 RAPD primers used, seven of them produced scorable bands (Table 2). These seven RAPD pri- mers yielded 84 polymorphic bands, which is 12 polymorphic RAPD bands per primer (Fig. 3).

AMOVA revealed $21.3 \%$ of the genetic variation among and $78.7 \%$ within populations (Table 3). In UPGMA dendrogram based on Nei's genetic distances the studied populations were grouped into two clusters. Similar to the morphological analysis, the populations from the northern part of Croatia (Dilj, Papuk, Samobor, Lanišće, Grobnik) formed one group and populations from the southern part another one (Pula, Jablanac, Šibenik, Imotski, Pelješac) (Fig. 4). Considering the results of the cluster analysis, we conducted an additional AMOVA in which the populations were arranged in these two geographical groups. In this analysis was observed $12.4 \%$ of molecular variance between the groups of populations, which supports the results of the cluster analysis. All AMOVA variations were found to be highly significant $(\mathrm{p}<0.001)$ (Table 3$)$.

Maximum genetic distance (Gst) and minimum gene flow $(\mathrm{Nm})$ were between populations Dilj and Imotski and minimum genetic distance and maximum gene flow were between populations Papuk and Samobor. Mean Gst among all analyzed populations was 0.14 while mean $\mathrm{Nm}$ was 2.39. Mean Gst within both geographical groups which were supported by the cluster analysis was 0.08 respectively, while mean Gst between these groups was 0.20 . Mean Nm within geographical groups was 4.21 (north populations) and 3.19 (south populations), while mean $\mathrm{Nm}$ among these groups was 1.38 (Table 4).

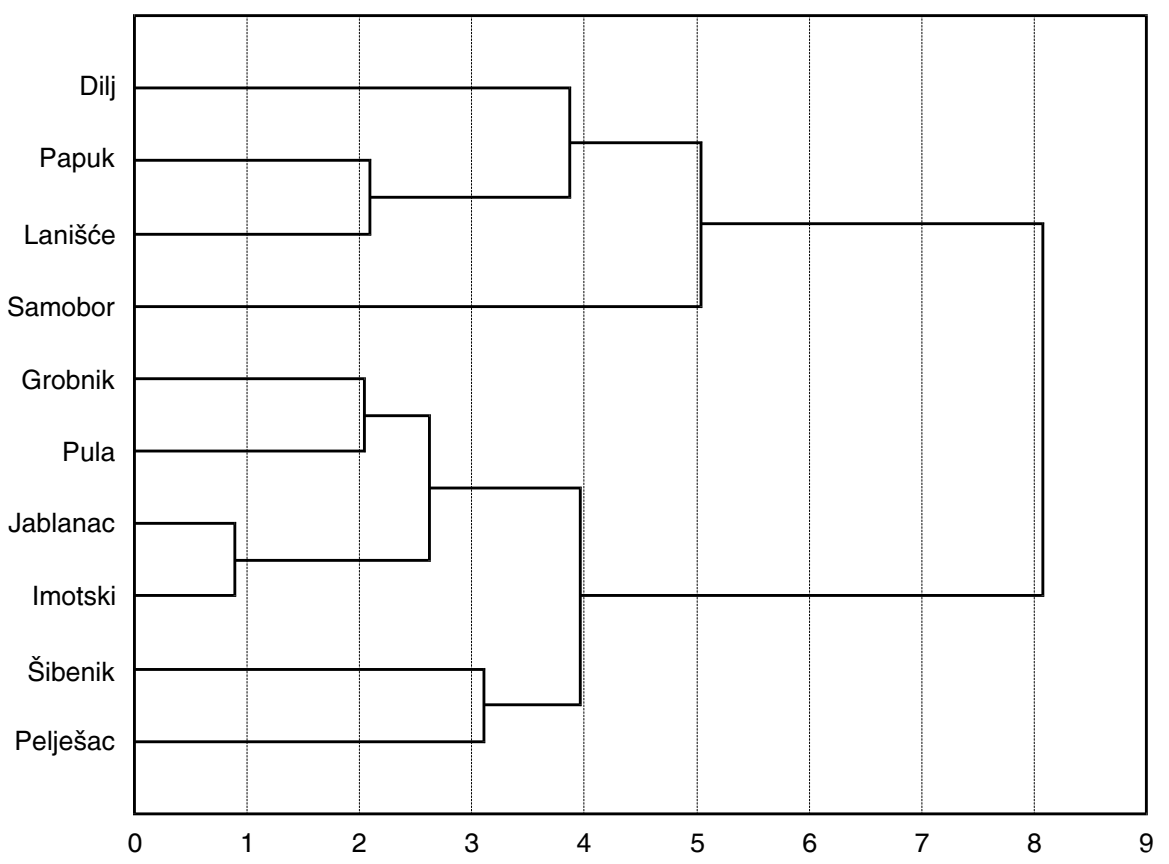

Fig 2. Cluster analysis (UPGMA method) of 10 populations of Quercus pubescens based on morphology of leaves and Mahalanobis' distance.

TABLE 2. RAPD primers that produced useful polymorphic bands among $Q$. pubescens accessions.

\begin{tabular}{lcc}
\hline RAPD primer & Number of polymorphic bands & Size of polymorphic bands (bp) \\
\hline OPB-02 (5'-TGATCCCTGG) & 8 & $500-2100$ \\
OPB-04 (5'-GGACTGGAGT) & 12 & $400-1950$ \\
OPB-10 (5'-CTGCTGGGAC) & 15 & $500-2300$ \\
OPB-11 (5'-GTAGACCCGT) & 8 & $550-1800$ \\
OPB-17 (5'-AGGGAACGAG) & 17 & $300-2000$ \\
OPB-18 (5'-CCACAGCAGT) & 14 & $450-1750$ \\
OPX-04 (5'-CCGCTACCGA) & 10 \\
\hline
\end{tabular}


$123 \quad 3 \quad 4 \quad 5 \quad 6 \quad 7 \quad 8 \quad 9101112 \quad 13141516171819202122232425 \mathrm{M} 26272829303132333435 \quad 363738394041424344454647484950$

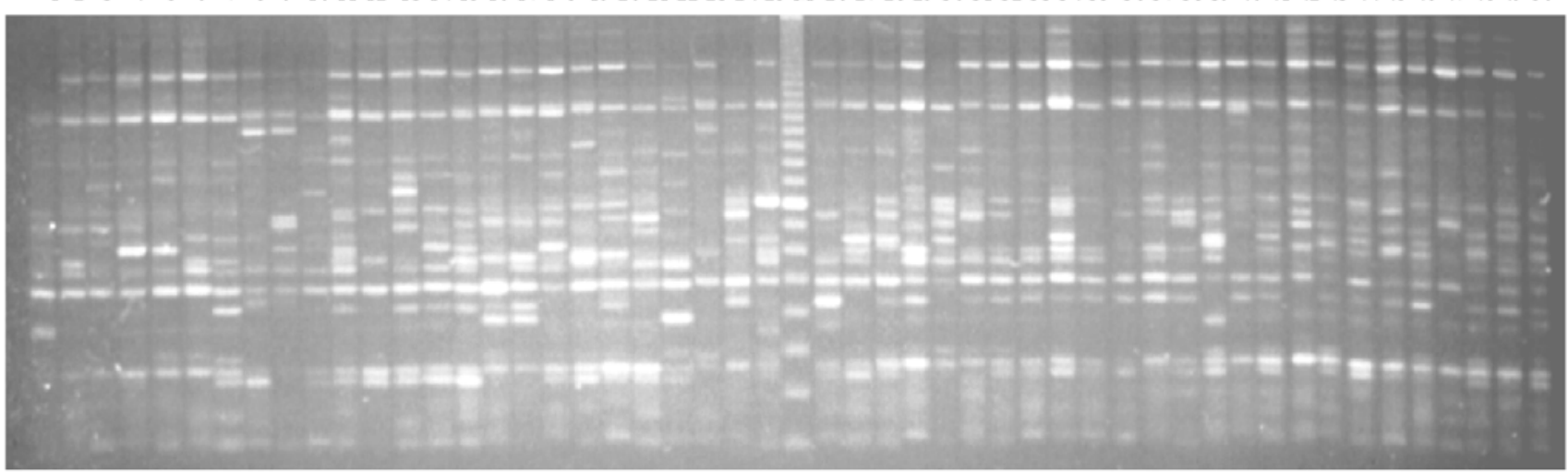

51525354555657585960616263646566676869707172737475 M 767778798081828384858687888990919293949596979899100

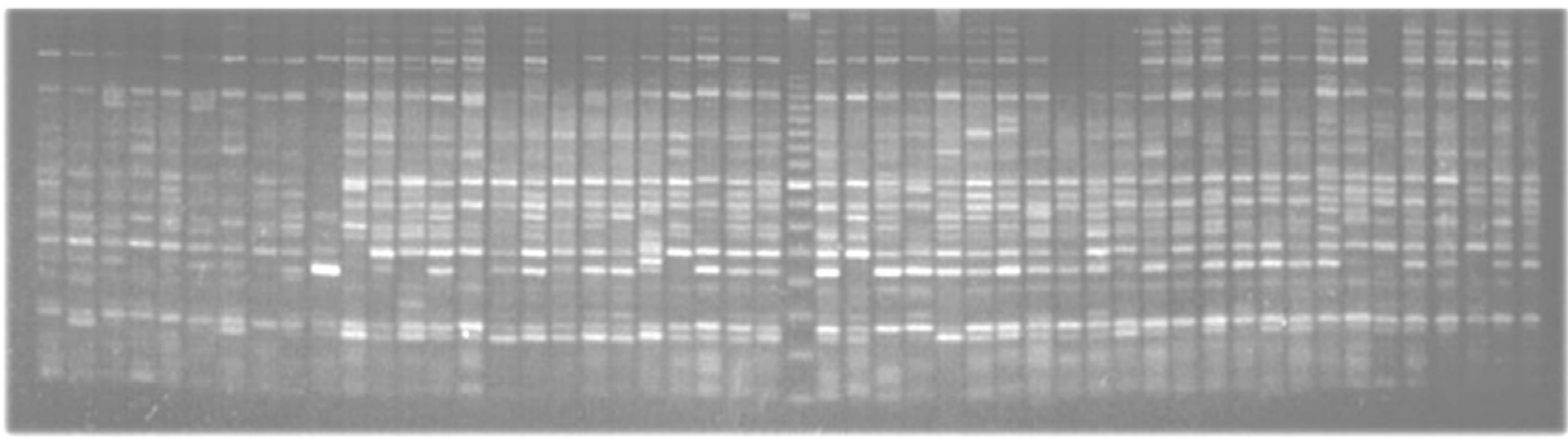

Fig. 3. RAPD profiles from Quercus pubescens s. 1. accessions generated by OPB-17 primer: M = 100 bp PCR Molecular Ruler (BIO-RAD $\left.{ }^{\circledR}\right)$; lanes 1-100 accessions from populations: Dilj (1-10), Papuk (11-20), Samobor (21-30), Grobnik (31-40), Lanišće (41-50), Pula (51-60), Jablanac (61-70), Šibenik (71-80), Imotski (81-90), Pelješac (91-100).

TABLE 3. Summary of analysis of molecular variance

\begin{tabular}{|c|c|c|c|c|}
\hline Level of variation & SS & MS & $\%$ & $p$ \\
\hline \multicolumn{5}{|l|}{ Without population grouping } \\
\hline Among populations & 82.350 & 9.150 & 21.3 & $<0.001$ \\
\hline Within populations & 221.900 & 2.466 & 78.7 & $<0.001$ \\
\hline \multicolumn{5}{|l|}{ Populations grouped in two groups } \\
\hline Between groups & 27.470 & 27.470 & 12.4 & $<0.001$ \\
\hline Among populations within groups & 54.880 & 6.860 & 13.2 & $<0.001$ \\
\hline Within populations & 221.900 & 2.466 & 74.4 & $<0.001$ \\
\hline
\end{tabular}

SS - sums of squares; MS - mean squares; $\%$ - proportion of genetic variability; $p$ - level of significance

\section{DISCUSSION}

The results of ANOVA and AMOVA, like in the other studies of long-lived woody perennials and wind-pollinated species (e.g. Hamrick and Godt 1990; Franjić 1996; Baliuckas et al. 1999; Rehfeldt 1999; Kovačić and Šimić 2001; Bruschi et al. 2003), show higher morphological and genetic variation within populations than among themselves (Table 1 and 3 ). The $21.3 \%$ of differentiation among populations and $78.7 \%$ within populations is similar result to other RAPD studies of outcrossing species (e.g. Reisch et al. 2005; Krüger et al. 2002; Nebauer et al. 1999) or to Q. petraea microsatellites study (Bruschi et al. 2003b).

The results of this study confirm, with no doubt, a high variability of the $Q$. pubescens in this area, but these differences can not confirm the views on existing of several species in this area, as some studies have stated so far (Trinajstić 1986; Bačić 1996). Contrary to that, morphological and molecular analyses divide all the Croatian populations of pubescent oak only into southern (Mediterranean) and northern (Continental) groups (Figs 2 and 4). These two groups are separated so strongly that, for example, the estimated gene flow among them $(\mathrm{Nm})$ is significantly lower than among the populations of the same group (Table 4). Although Nm is only estimation based on Gst, it reflects the degree of population differentiation.

There is a remarkable congruence between the results of this study and the results of the most recent researches that deny the existence of several species within the complex of Q. pubescens (Bussotti and Grossoni 1997; Uzunova et al. 1997) and affirm differentiation between the Central and South European Q. pubescens populations (Müller and Aas 1997; Müller 1999).

Comparing the results of this study with the results of the recent researches of the $Q$. pubescens in Central Europe (Samuel et al. 1995; Müller and Aas 1997; Aas 1998; Müller 1999, Bruschi et al. 2000, 2003a, b; Škvorc et al. 2005) we can conclude that the differences found between 


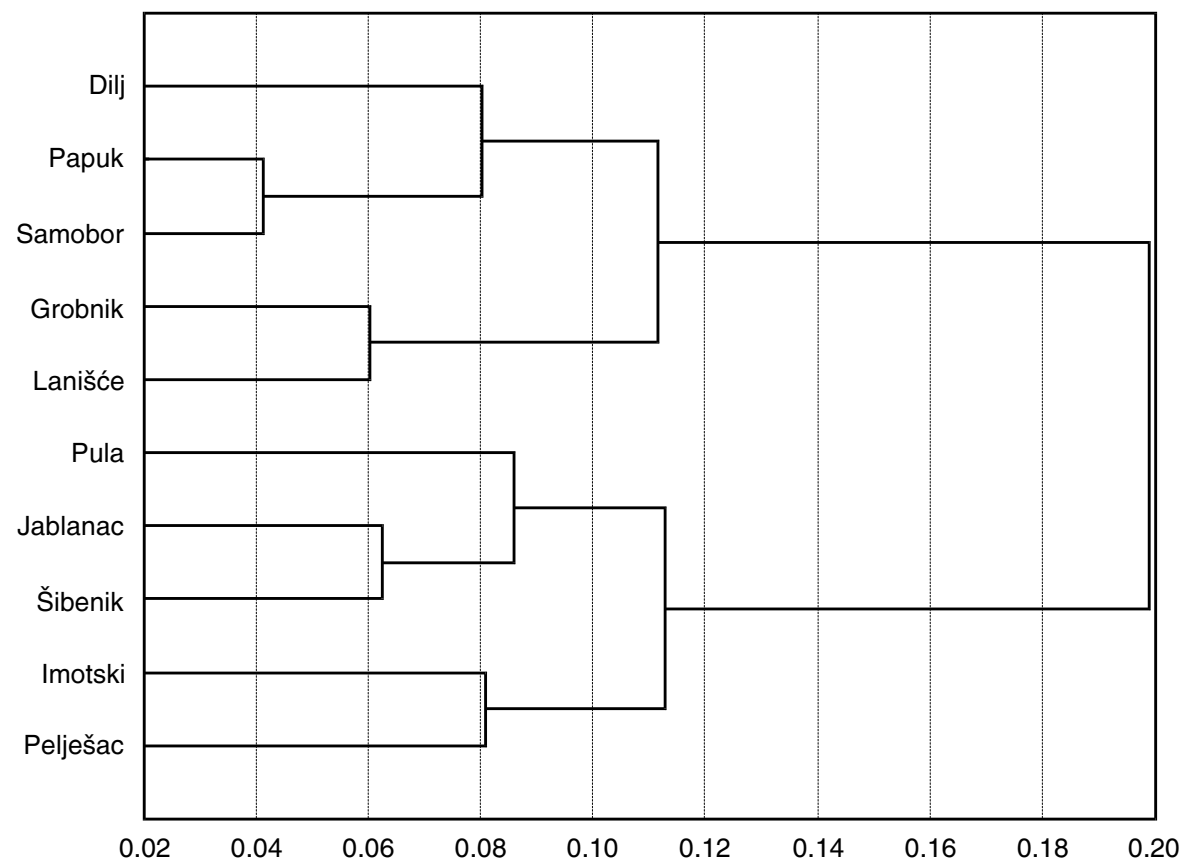

Fig. 4. Cluster analysis (UPGMA method) of 10 populations of Quercus pubescens based on RAPD data and Nei's genetic distance.

TABLE 4. Pairwise Nei's genetic distances (Gst - below diagonal) and gene flow among populations (Nm - above diagonal).

\begin{tabular}{|c|c|c|c|c|c|c|c|c|c|c|}
\hline Population & Dilj & Papuk & Samobor & Grobnik & Lanišće & Pula & Jablanac & Šibenik & Imotski & Pelješac \\
\hline Dilj & $* * * *$ & 2.71 & 6.69 & 2.46 & 1.33 & 1.63 & 0.77 & 1.04 & 0.52 & 0.70 \\
\hline Papuk & 0.08 & ***** & 14.37 & 2.69 & 2.24 & 1.61 & 0.88 & 0.85 & 0.69 & 0.81 \\
\hline Samobor & 0.04 & 0.02 & $* * * *$ & 4.10 & 4.05 & 2.02 & 1.24 & 1.46 & 0.81 & 0.95 \\
\hline Grobnik & 0.09 & 0.09 & 0.06 & $* * * *$ & 1.50 & 2.04 & 1.79 & 1.29 & 0.97 & 0.81 \\
\hline Lanišće & 0.16 & 0.10 & 0.06 & 0.14 & $* * * *$ & 1.98 & 1.37 & 3.39 & 1.83 & 2.15 \\
\hline Pula & 0.13 & 0.13 & 0.11 & 0.11 & 0.11 & $* * * *$ & 3.01 & 4.08 & 1.88 & 2.53 \\
\hline Jablanac & 0.25 & 0.22 & 0.17 & 0.12 & 0.15 & 0.08 & $* * * *$ & 5.28 & 2.12 & 1.52 \\
\hline Šibenik & 0.19 & 0.23 & 0.15 & 0.16 & 0.07 & 0.06 & 0.05 & ***** & 3.92 & 3.60 \\
\hline Imotski & 0.32 & 0.27 & 0.24 & 0.20 & 0.12 & 0.12 & 0.11 & 0.06 & $* * * *$ & 3.91 \\
\hline Pelješac & 0.26 & 0.24 & 0.21 & 0.24 & 0.10 & 0.09 & 0.14 & 0.06 & 0.07 & $* * * *$ \\
\hline
\end{tabular}

northern and southern Croatian populations exist probably due to introgression of the $Q$. petraea (Matt.) Liebl. into the genome of the $Q$. pubescens. In other words, $Q$. pubescens in Central Europe was pushed out to very small and isolated areas of southern expositions where they exchange territory with $Q$. petraea. Due to the favourable ecological conditions, hybrids between those two species often manage to survive, so what is thought to be $Q$. pubescens in the Central Europe area (and likely in northern Croatia) in a certain way represents the transition form between $Q$. pubescens and Q. petraea (Samuel et al. 1995; Müller 1999). Because of the completely different ecological conditions $Q$. petraea occurs only as a rarity in southern Europe (Trinajstić 1974, 1986; Bruschi 2003b) and hybrids between $Q$. pubescens and $Q$. petraea are really rare in that region (Trinajstić 1974; Müller 1999; Škvorc et al. 2005). Since the mentioned hybrids have no chance to survive due to strong selection pressures that favour the genome of the more thermophilic species, the group of the southern Croatian populations probably represents pure $Q$. pubescens populations. Finally, the higher gene flow among Continental than Mediterranean populations noticed in this study (Table 4), in spite of the fact that Continental populations are smaller and more scattered, could be also outcome of $Q$. petraea introgression.
The difference between morphological analysis of leaves and RAPD analysis is most obvious in the Grobnik population which is sorted into the southern group by the morphological analysis, while the molecular analysis sorts it into the northern group of populations (Figs 2 and 4, Tables 1 and 4 ). Since the results of some previous studies connected the morphological traits of leaves with latitudinal and altitudinal range of populations, but also with different climatologic factors (e.g. Kleinschmit 1993; Škvorc et al. 2005), the settlement of Grobnik population, in morphological analysis in the southern group, can be explained by similar stand characteristics. Contrary to that, the results of molecular analysis can be connected to the fact that Grobnik population (unlike the other southern populations) is situated in contact area with the $Q$. petraea populations (like the other northern populations). This fact and the results from some previous studies, that try to delimit $Q$. petraea and $Q$. pubescens in morphological and molecular way (e.g. Bruschi et al. 2000; Skvvorc et al. 2005), lead to the conclusion that RAPD profile of Grobnik population indicates possible $Q$. petraea introgression into the genome of $Q$. pubescens. The main difference between Grobnik population and the other continental populations in this research is that the possible $Q$. petraea introgression in Grobnik population is obvious only through molecular but not through 
morphological characteristics. Due to the evident transitional characteristics of the Grobnik population and partly of Istrian population Lanišće (Figs 2 and 4; Tables 1 and 4), this region (Fig. 1) could be a place where Q. petraea introgression into the genom of the $Q$. pubescens gradually fade away towards the South.

From the conservation perspective the high variability and high level of gene flow among populations is encouraging (Tables 1, 3 and 4). Although continental populations are small and scattered, because of the intensive gene flow there is no risk of extinction (Table 4). Moreover, Q. pubescens could be the source of genes necessary for the survival of oaks in Middle Europe. It is especially important referring to the eventual climate changes connected to global warming and different anthropogenic impacts (Aas 1998; Müller 1999). The results of this research confirm that, in the conservation strategy, an oak species must not to be observed as isolated and static species but as a complex system where populations of other oak species can change its genome (Harrison and Hastings 1996).

In order to make the final confirmation of the stated theory about the introgression of the Quercus petraea populations, it is necessary to find the molecular markers specific to the Q. petraea (Samuel et al. 1995; Bruschi et al. 2000), and then to detect them in the Croatian $Q$. pubescens populations. If such specific molecular markers could be found, it would be possible to connect ecological conditions with the genetic constitution of each individual. These results would be of great benefit to future researches, as well as management and conservation of these species.

\section{LITERATURE CITED}

AAS G. 1998. Morphologische und ökologische Variation mitteleuropäischer Quercus-Arten: Ein Beitrag zum Verständnis der Biodiversität. Libri Botanici: Band 19. IHW-Verlag, Eching.

BAČIĆ T. 1996. Note on use of some micro-morphological features in distinction of three pubescent oaks in Croatia. Acta Biol. Crac. Ser. Bot. 38: 67-79.

BACILIERI R., DUCOUSSO A., KREMER A. 1996. Comparison of morphological characters and molecular markers for the analysis of hybridization in sessile and pedunculate oak. Ann. Sci. For. 53: 79-91.

BALIUCKAS V., EKBERG I., ERIKSSON G., NORELL L. 1999. Genetic variation among and within populations of four Swedish hardwood species assessed in a nursery trial. Silvae Genet. 48(1): 17-25.

BLUE M.P., JENSEN R.J. 1988. Positional and seasonal variation in oak (Quercus: Fagaceae) leaf morphology. Am. J. Bot. 75: 939-947.

BRUSCHI P., VENDRAMIN G.G., BUSSOTTI F., GROSSONI P. 2000. Morphological and molecular differentiation between Quercus petraea (Matt.) Liebl. and Quercus pubescens Willd. (Fagaceae) in northern and central Italy. Ann. Bot. 85: 325-333.

BRUSCHI P., GROSSONI P., BUSSOTTI F. 2003a. Within- and among-tree variation in leaf morphology of Quercus petraea (Matt.) Liebl. natural populations. Trees 17: 164-172.

BRUSCHI P., VENDRAMIN G.G., BUSSOTTI F., GROSSONI P. 2003b. Morphological and molecular diversity among Italian populations of Quercus petraea (Fagaceae). Ann. Bot. 91(6): 707-716.

BURGER W.C. 1975. The species concept in Quercus. Taxon 24: 45-50.

BUSSOTTI F., GROSSONI P. 1997. European and Mediterranean oaks (Quercus L.; Fagaceae): SEM characterization of the micromorphology of the abaxial leaf surface. Bot. J. Linn. Soc. 124: 183-199.

DUMOLIN S., DEMESURE B., PETIT R.J. 1995. Inheritance of chloroplast and mitochondrial genomes in pedunculate oak investigated with an efficient PCR method. Theor. Appl. Genet. 91: 1253-1256.

DUPOUEY J.L., BADEAU V. 1993. Morphological variability of oaks (Quercus robur L., Q. petraea (Matt.) Liebl., Q. pubescens Willd.) in northeastern France: preliminary results. Ann. Sci. For. 50: 35-40.

EXCOFFIER L., SMOUSE P.E., QUATRO J.M. 1992. Analysis of molecular variance inferred from metric distances among DNA haplotypes: application to human mitochondrial DNA restriction data. Genetics 131: 479-491.

FRANJIĆ J. 1996. Multivariate analysis of leaf properties in the common oak (Quercus robur L., Fagaceae) populations of Posavina and Podravina in Croatia. Ann. Forest. 21: 23-60.

HAMRICK J.L., GODT J.W. 1990. Allozyme diversity in plant species. In: Brown A.H.D., Clegg M.P., Kahler L., Weir B.S. (eds). Plant populations genetics. Breeding and genetic resources. Sunderland, Sinauer, 43-63.

HARRISON S., HASTINGS A.M. 1996. Genetic and evolutionary consequences of metapopulation structure. Trends Ecol. Evol. 11: 180-183.

HILLIS D.M., MORITZ C., MABLE B.K. 1996. Molecular systematics, 2nd edition. Sinauer Associates Inc., Massachusetts.

HOWARD D.J., PRESZLER R.W., WILLIAMS J., FENCHEL S., BOECKLEN W.J. 1997. How discrete are oak species - insights from a hybrid zone between Quercus grisea and Quercus gambelii. Evolution 51: 747-755.

KLEINSCHMIT J. 1993. Intraspecific variation of growth and adaptive traits in European oak species. Ann. Sci. For. 50: 166-185

KOVAČIĆ S., ŠIMIĆ D. 2001. Intrapopulational and interpopulational relations of Betula pendula Roth (Betulaceae) in Croatia, based on leaf morphometry. Acta Biol. Crac. Ser. Bot. 43: 87-96.

KRÜGER A.M., HELLWIG F.H., OBERPRIELER C. 2002. Genetic diversity in natural and anthropogenic inland populations of salt-tolerant plants: random amplified polymorphic DNA analyses of Aster tripolium L. (Compositae) and Salicornia ramosissima Woods (Chenopodiaceae). Mol. Ecol. 11: 1647-1655.

LIBER Z., NIKOLIĆ T., MITIĆ B. 2002. Plant DNA isolation from differently preserved Thalictrum leaf tissues and their use in RAPD analysis. Acta Biol. Crac. Ser. Bot. 44: 73-77.

MANOS P.S., DOYLE J.J., NIXON K.C. 1999. Phylogeny, biogeography, and processes of molecular differentiation in Quercus, Subgenus Quercus (Fagaceae). Mol. Phylogenet. Evol. 12: 333-349.

MOREAU F., KLEINSCHMIT J., KREMER A. 1994. Molecular differentiation $Q$. petraea and $Q$. robur assessed by random amplified DNA fragments. For. Genet. 1: 51-64.

MUIR G., FLEMING C.C., SCHLÖTTERER C. 2000. Species status of hybridizing oaks. Nature 405: 1016.

MÜLLER B. 1999. Variation und hybridisierung von Quercus pubescens. Diss. ETH Nr. 13025

MÜLLER B., AAS G. 1997. Species-specific variability of Quercus pubescens in central Europe. In: K.C. Steiner (ed.): Diversity and adaptation in oak species. Proceedings of the second meeting of IUFRO working party 2.08.05, Genetics of Quercus, October 12-17, 1997, University park, Pennsylvania USA, pp. 132-140.

MULLIS K.B., FALOONA F.A. 1987 Specific synthesis of DNA in vitro via a polymerase catalyzed chain reaction. Methods Enzymol. 155: 335-350.

NEBAUER S.G., del CASTILLO-AGUDO L., SEGURA L. 1999. RAPD variation within and among natural poulations of outcrossing willow-leafed foxglove (Digitalis obscura L.). Theor. Appl. Genet. 98: 985-994. 
PEAKALL R., SMOUSE P.E. 2001. GenAlEx: Genetic Analysis in Excel. Canberra: Australian National University http://www. anu.edu.au/BoZo/GenAlEx.

PETIT R.J., BREWER S., BORDACS S., BURG K., CHEDDADI R., COART E., CSAIKL U.M., DAM VAN B., DEANS J.D., ESPINEL S., FINESCHI S., FINKELDEY R., GLAZ I., GOICOECHEA P.G., JENSEN J.S., KÖNIG A.O., LOWE A.J., MADSEN S.F., MATYAS G., MUNRO R.C., POPESCU F., SLADE D., TABBENER H., VRIES DE S.G. M., ZIEGENHAGEN B., BEAULIEU DE J.L., KREMER A. 2002. Identification of refugia and post-glacial colonisation routes of European white oaks based on chloroplast DNA and fossil pollen evidence. For. Ecol. Manage. 156: 49-74.

PIGNATTI S. 1997. Flora d'Italia 1. Edagricole. Bologna

REHFELDT G.E. 1999. Systematics and genetic structure of washoe pine: Applications in conservation genetics. Silvae Genet. 48(3-4): 167-173.

REISCH C., ANKE A., RÖHL M. 2005. Molecular variation within and between ten populations of Primula farinosa (Primulaceae) along an altitudinal gradient in the northern Alps. Basic Appl. Ecol. 6: 35-45.

RUSHTON B.S. 1993. Natural hybridization within the genus Quercus L. Ann. Sci. For. 50: 73-90.

SAMBROOK J., FRITCH E.F., MANIATIS T. 1989. Molecular cloning: A laboratorial manuel. Cold Spring Harbor Laboratory Press, New York.

SAMUEL R., PINSKER W., EHRENDORFER F. 1995. Electrophoretic analysis of genetic variation within and between populations of Quercus cerris, $Q$. pubescens, $Q$. petraea and $Q$. robur (Fagaceae) from Eastern Austria. Bot. Acta 108: 290-299.

SCHWARZ O. 1964. Quercus L. In: T.G. Tutin, V.H. Haywood, N.A. Burges, D.H. Valentine, S.M..Walters, D.A. Webb (eds). Flora Europaea 1, pp. 61-64.

SOKAL R.R., ROHLF F.J. 1989. Biometry. Freeman and CO, San Francisco.

SOLTIS D.E., SOLTIS P.S., DOYLE J.J. 1998. Molecular systematics of plants II. Kluwer academic publishers, Boston.

ŠKVORC Ž., FRANJIĆ J., IDŽOJTIĆ M. 2005. Population structure of Quercus pubescens Willd. (Fagaceae) in Croatia according to morphology of leaves. Acta Bot. Hung. 47(1-2): 193-206.
TRINAJSTIĆ I. 1974. Quercus L. Analitička Flora Jugoslavije 1: 460-481.

TRINAJSTIĆ I. 1986. Fitogeografsko raščlanjenje šumske vegetacije istočnojadranskog sredozemnog područja - polazna osnovica u organizaciji gospodarenja mediteranskim šumama. (Phytogeographical separation of the forest vegetation of EastAdriatic region - the start point for the organization of the management of Mediterranean forests). Glasnik za šumarske Pokuse Posebno Izdanje 2: 53-67. (in Croatian)

TRINAJSTIĆ I., FRANJIĆ J. 1996. Listovi kratkoga plodnoga izbojka, osnova za morfometrijsku analizu lista hrasta lužnjaka (Quercus robur L., Fagaceae). (The leaves of the short fertile shoot, base for the morphometric analysis of the leaves of common oak). In: S. Matić, J. Gračan (ed.). Skrb za hrvatske šume od 1846. do 1996. Unapreðenje proizvodnje biomase šumskih ekosustava 1. (Care for Croatian forests from 1846 to 1996. Improvement of production of biomass in forest ecosystems) - Hrvatsko šumarsko društvo, Zagreb, p. 169-178. (in Croatian)

UZUNOVA K., PALAMAREV E., EHRENDORFER F. 1997 Anatomical changes and evolutionary trends in the foliar epidermis of extant and fossil Euro-Mediterranean oaks (Fagaceae). Pl. Syst. Evol. 204: 141-159.

WELSH J., MCCLELLAND M. 1990. Fingerprinting genomes using PCR with arbitrary primers. Nucleid Acids Res. 1: 7213$-7218$.

WILLIAMS J.G.K., KUBELIK A.R., LIVAK K.J., RAFALSKI J.A., TINGEY S.V. 1990. DNA polymorphisms amplified by arbitrary primers are useful as genetic markers. Nucleic Acids Res. 18: 6531.

WOLFE A.D., LISTON A. 1998. Contributions of PCR-Based Methods to Plant Systematics and Evolutionary Biology. In: D.E. Soltis, P.S. Soltis, J.J. Doyle (eds). Molecular systematics of plants II, Kluwer academic publishers, Boston, pp. 43-86.

WRIGHT S. 1951. Variability within and among natural populations. The University of Chicago Press, Chicago.

YEH F.C., YANG R., BOYLE T.B.J., YE Z., MAO J.X. 1997. POPGENE, the user-friendly shareware for population genetic analysis. Molecular Biology and Biotechnology Center, University of Alberta, Canada. 